REFLEKSI HUKUM

Jurnal Ilmu Hukum
p-ISSN 2541-4984 | e-ISSN 2541-5417

Volume 3 Nomor 2, April, Halaman 161-174

DOI: https://doi.org/10.24246/jrh.2019.v3.i2.p161-174

Open access at: http://ejournal.uksw.edu/refleksihukum

Penerbit: Fakultas Hukum Universitas Kristen Satya Wacana

\title{
PERGESERAN FUNGSI DAN KEDUDUKAN BADAN PERMUSYAWARATAN DESA MENURUT UNDANG-UNDANG NOMOR 6 TAHUN 2014 TENTANG DESA (STUDI BPD DESA KUNJANG)
}

\author{
Galuh Candra Purnamasari \\ Universitas Katolik Parahyangan \\ Korespondensi: galuhcandra278@gmail.com
}

\begin{abstract}
Abstrak
Penelitian ini membahas pergeseran fungsi dan kedudukan Badan Permusyawaratan Desa menurut Undang-Undang Nomor 6 Tahun 2014 tentang Desa dan pengaruh pergeseran tersebut khususnya bagi Badan Permusyaratan Desa Kunjang. Metode yang digunakan dalam penelitian ini adalah yuridis normatif dengan pendekatan perundang-undangan dan pendekatan historis. Kesimpulan yang didapatkan dari penelitian ini adalah pergeseran kedudukan dan fungsi Badan Permusyawaratan Desa memberikan pengaruh kepada Badan Permusyawaratan DesaKunjang yaitu pertama, Badan Permusyawaratan Desa Kunjang tidak lagi menjadi unsur penyelenggara pemerintahan desadan sebagai "mitra" kepala desa dalam menyelenggarakan Pemerintahan Desa Kunjang. Kedua, fungsi pengawasan menjadi fungsi utama dari Badan Permusyawaratan Desa Kunjang, berbeda dengan fungsi legislasi yang menjadi tugas dan tanggung jawab utama dari Pemerintah Desa Kunjang dan bukan menjadi tugas dan tanggung jawab utama dari Badan Permusyawaratan Desa Kunjang.
\end{abstract}

Kata Kunci: Badan Permusyawaratan Desa; Kedudukan Badan Permusyawaratan Desa; Fungsi Badan Permusyawaratan Desa.

\begin{abstract}
This research discusses the effect of shifting the function and the state of the Village Consultative Body according to Law No. 6 of 2014 on Village. The study particularly took observation in Kunjang Village. The used method in this paper is normative research which applies legislation approach and historical approach. The final conclusion resulted by this research is the shift of function and the state of the Village Consultative Body had influenced the state of the Village Consultative Body Kunjang. First, the state of the Village Consultative Body Kunjang is no longer an element of village administration and as a "partner" of the headman. Second, the monitoring function becomes the only main function of the state of the Village Consultative Body Kunjang, whereas the legislative function becomes the duty of the Kunjang Village Government, stressing that the legislative function is not part of the main duty and responsibility of the Village Consultative Body Kunjang.
\end{abstract}

Keywords: Village Consultative Body; The State of Village Consultative Body; The Function Of Village Consultative Body. 


\section{PENDAHULUAN}

Desa merupakan satuan masyarakat hukum yang mempunyai wilayah, penduduk dan pemerintahannya sendiri. Pemerintahan desa telah ada dan diakui sebelum Indonesia merdeka oleh Pemerintah Kolonial Belanda. Pemerintah Indonesia juga mengakui keberadaan desa tersebut sebagai satuan pemerintah terendah dari Negara Kesatuan Republik Indonesia (NKRI). 1 Secara perspektif yuridis politis, desa dipandang sebagai suatu pemerintahan terendah di Indonesia atau kesatuan masyarakat hukum yang mempunyai identitas, entitas, memiliki batas-batas wilayah tertentu dan memiliki kewenangan untuk mengatur dan mengurus kepentingan masyarakat setempat, berdasarkan asal usul dan adat istiadat setempat yang diakui dan dihormati dalam sistem pemerintahan NKRI. ${ }^{2}$ Salah satu badan yang ada di Desa adalah Badan Permusyawaratan Desa (yang selanjutnya disingkat BPD).

Pasal 1 angka 4 Undang-Undang Nomor 6 Tahun 2014 tentang Desa (selanjutnya disebut UU Desa) menyatakan BPD adalah lembaga yang melaksanakan fungsi pemerintahan yang anggotanya merupakan wakil dari penduduk desa berdasarkan keterwakilan wilayah dan ditetapkan secara demokratis. Berdasarkan Pasal tersebut, BPD telah mengalami pergeseran kedudukan, dimana BPD bukan menjadi unsur penyelenggara pemerintahan desa. Penyelenggara pemerintah desa adalah kepala desa dibantu oleh perangkat desa, sedangkan BPD dikatakan sebagai lembaga yang melaksanakan fungsi pemerinta- han. Fungsi pemerintahan tersebut antara lain menampung dan menyalurkan aspirasi masyarakat, melaksanakan tugas pengawasan kinerja kepala desa, serta bersama-sama dengan kepala desa membahas dan menyepakati Rancangan Peraturan Desa (raperdes). Pergeseran kedudukan BPD sebagai penyelenggara pemerintahan desa menjadi suatu lembaga yang menjalankan fungsi pemerintahan menimbulkan pertanyaan. Bagaimana pengaruh BPD yang berada di luar penyelenggara pemerintahan desa terhadap kedudukan BPD khususnya di Desa Kunjang?

Fungsi pengawasan yang dimiliki oleh BPD juga mengalami perubahan semenjak diundangkannya UU Desa. Hal tersebut menimbulkan permasalahan, bagaimana pergeseran fungsi pengawasan tersebut mengingat kedududukan BPD yang berada di luar penyelenggara pemerintahan desa? Bagaimana peran BPD khususnya BPD Kunjang sebagai suatu lembaga dalam mengawasi penyelenggara pemerintahan desa, sebagai contoh mengawasi penggunaan dana desa oleh pemerintah desa?

Berkaitan dengan fungsi legislasi, dapat dipertanyakan apakah fungsi legislasi yang dimiliki BPD dapat 'disamakan' dengan fungsi legislasi yang dimiliki oleh DPRD ataupun DPR? Bagaimana kewenangan BPD sebagai suatu lembaga dalam pembentukan perdes? Apabila tidak terjadi kesepakatan antara kepala desa dan perangkat desa dan BPD terkait dengan raperdes, maka langkah apa yang dilakukan terhadap raperdes yang bersangkutan? 
Berkaitan dengan fungsi perwakilan, UU Desa dan Peraturan Menteri Dalam Negeri (Permendagri) No. 110 Tahun 2016 tentang Badan Permusyawaratan Desa hanya menyatakan pemilihan anggota BPD dilakukan secara demokratis melalui proses pemilihan secara langsung atau musyawarah perwakilan. Hal ini dapat mengakibatkan kedudukan BPD sebagai suatu lembaga menjadi kabur, apakah BPD diposisikan sebagai lembaga yang mewakili masyarakat desa atau sebagai lembaga politik? Bagaimana dengan demokrasi yang dijalankan oleh BPD sebagai wadah aspirasi masyarakat desa?

Berdasarkan permasalahan yang telah diuraikan di atas, maka dalam tulisan ini akan dibahas lebih lanjut mengenai pergeseran kedudukan dan fungsi BPD, baik secara umum maupun khusus di Desa Kunjang yang dilihat dari pendekatan perundang-undangan dan pendekatan historis. Data yang digunakan dalam penelitian ini menggunakan data sekunder yang diperoleh dari studi pustaka dan data primer yang didapat dari studi lapangan sebagai data pendukung. Hasil penelitian kemudian disajikan secara deskriptif.

\section{PEMBAHASAN}

Desa atau sebutan-sebutan lain yang sangat beragam di Indonesia, pada awalnya merupakan organisasi komunitas lokal yang mempunyai batas-batas wilayah, dihuni oleh sejumlah penduduk, dan mempunyai adai istiadat untuk mengelola dirinya sendiri yang disebut self-governing community. ${ }^{3}$ Terbentuknya desa sebagai tempat tinggal kelompok terutama disebabkan karena naluri alamiah untuk mempertahankan kelompok. Di dalam kelompok tersebut terjalin sendi-sendi yang melandasi hubungan-hubungan antara sesama warga kelompok berdasarkan hubungan kekerabatan, karena tinggal di wilayah yang dekat ataupun karena kesamaan kepentingan. ${ }^{4}$ Soetardjo mengemukakan bahwa desa adalah kesatuan hukum, dimana masyarakat bertempat tinggal dan berkuasa mengadakan pemerintah sendiri. ${ }^{5}$ Desa-desa tersebut ada sejak berabad-abad lamanya dan mengalami perkembangan menjadi satu kesatuan hukum, dimana hukum tersebut memuat dua hal, pertama hak untuk mengurus kepentingan daerah sendiri yang dalam istilah sekarang disebut hak otonom dan kedua hak untuk memilih kepala desanya sendiri. Hak otonom tersebut bersifat sangat luas sehingga hampir seluruh permasalahan seperti hukum keluarga, hukum waris, hukum tanah, hukum perdata dan hukum pidana termasuk di dalamnya. ${ }^{6}$ Sebutan desa sebagai kesatuan masyarakat hukum dikenal pada masa kolonial Belanda yang secara garis besar dapat dibagi atas 3 (tiga) tipe, yaitu tipe kesatuan masyarakat hukum berdasarkan wilayah/teritorial, tipe kesatuan masyarakat hukum berdasarkan kesamaan keturunan dan tipe kesatuan masyarakat hukum berdasarkan asas campuran (teritorial dan keturunan). ${ }^{7}$

\footnotetext{
3 Ni'matul Huda, Hukum Pemerintahan Desa Dalam Konstitusi Indonesia Sejak Kemerdekaan Hingga Era Reformasi (Setara Press 2015) 33.

Saparin, Tata Pemerintahan dan Administrasi Pemerintahan Desa (Ghalia Indonesia 1977) 117.

Soetardjo Kartohadikoesoemo, Desa (Jogyakarta 1953) 2.

Ibid., 9.

Unang Sunardjo, Tinjauan Singkat Tentang Pemerintahan Desa dan Kelurahan (Tarsito 1984) 10.
} 
Desa sebagai wilayah yang ditempati oleh sejumlah pewarisan dari UU pada zaman kolonial yaitu Inlandsche Gemeente Ordonantie (IGO) yang berlaku untuk Jawa dan Madura dan Inlandsche Gemeente Ordonantie Buitengewesten (IGOB) yang berlaku di luar Jawa dan Madura. Peraturan ini tidak mengatur desa secara seragam sehingga mengakibatkan desa dan pemerintahan desa dengan bentuk dan corak yang beraneka ragam. ${ }^{8}$ Namun perlu diperhatikan bahwa Belanda tidak ikut campur tangan dalam mengurus desa. 9 UU yang mengatur mengenai desa terus mengalami perkembangan hingga saat ini muncul UU Desa.

Desa memiliki hak untuk menjalankan dan mengurus pemerintahannya sendiri yang kemudian disebut dengan otonomi desa. Otonomi desa bersifat asli, yang berarti hak untuk menyelenggarakan pemerintahannya tersebut tidak diberikan oleh pemerintah pusat, melainkan hak tersebut sudah ada sejak dahulu kala dan negara mengakui keberadaan hak tersebut. Hal ini yang kemudian tercermin dalam Pasal 18B ayat (2) Undang-Undang Dasar Negara Republik Indonesia Tahun 1945 (UUD NRI 1945), dimana terdapat frasa "negara mengakui dan menghormati kesatuan-kesatuan masyarakat adat beserta hak-hak tradisionalnya sepanjang masih hidup dan sesuai dengan perkembangan masyarakat dan prinsip NKRI." Otonomi desa tentu berbeda dengan otonomi daerah, dimana dalam otonomi daerah hak untuk mengurus dan menjalankan pemerintahan diberikan oleh pusat kepada daerah berdasarkan asas desentralisasi. Sebaliknya, UUD NRI 1945 tidak menerapkan asas desentralisasi bagi pemerintahan desa. Oleh karena itu kewenangan desa itu hanya didasarkan pada asas rekognisi (pengakuan) dan subsidaritas dan bukan asas desentralisasi. ${ }^{10}$

\section{Sejarah Perkembangan Badan Permusyawaratan Desa}

Menurut IGO (Staatsblad 83 Tahun 1906) pemerintahan desa dilakukan oleh kepala desa dibantu oleh pegawai desa (parentah desa, perabot desa, bahu desa). ${ }^{11}$ Kepala desa wajib merundingkan hal-hal yang penting berkaitan dengan rumah tangga desa dengan rapat desa. Rapat desa tersebut terdiri dari parentah desa, warga desa yang berhak memilih kepala desa dan penduduk lain yang dianggap perlu menurut hukum adat. Rapat desa ini dianggap sebagai perwujudan demokrasi tertinggi dan sebagai pemegang kekuasaan tertinggi di desa. ${ }^{12}$ Hal ini menarik mengingat meskipun berdasarkan IGO (Staatsblad 83 Tahun 1906) rapat desa bukan menjadi unsur pelaksana/ penyelenggara pemerintahan desa, namun justru rapat desa menjadi lembaga tertinggi (berkedudukan di atas kepala desa dan parentah desa) dan memiliki kekuasaan tertinggi di desa. Demokrasi yang dilaksanakan oleh rapat desa saat itu merupakan demokrasi langsung, dimana seluruh

\footnotetext{
8 HAW Widjaja, Otonomi Desa Merupakan Otonomi Yang Asli, Bulat dan Utuh (Rajawali Press 2014) 10.

$9 \quad$ Ibid., 11.

10 Setiawati, 'Peran Badan Permusyawaratan Desa Dalam Penyusunan dan Penetapan Peraturan Desa' (2018) 5 Jurnal Pendidikan dan Kewarganegaraan Unpam 61, 62.

11 Soetardjo Kartohadikoesoemo, Op.Cit., 131.

12 Ni'Matul Huda, Op.Cit., 254.
} 
masyarakat desa dapat mengikuti rapat dan memberikan pendapat atas urusan rumah tangga desa. Rapat desa tersebut mempunyai 3 (tiga) fungsi, yaitu sebagai dewan penasehat bagi kepala desa, sebagai dewan legislatif untuk menetapkan peraturan dan anggaran belanja desa dan memberi persetujuan terhadap putusan kepala desa agar putusan kepala desa dapat dianggap sah. ${ }^{13}$ Rapat desa inilah yang menjadi embrio dari BPD yang kini dikenal.

Berbeda dengan rapat desa yang berkedudukan sebagai lembaga tertinggi dan bukan sebagai penyelenggara pemerintahan desa, badan musyawarah desapraja menurut UU No. 19 Tahun 1965 tentang Desapraja Sebagai Bentuk Peralihan Untuk Mempercepat Terwujudnya Daerah Tingkat III di Seluruh Wilayah Republik Indonesia menjadi salah satu unsur pelaksana/ penyelenggara pemerintahan desa bersama dengan kepala desapraja dan alat perlengkapan lain seperti pamong desapraja, panitera desapraja, petugas desapraja dan badan pertimbangan desapraja. Kedudukan badan musyawarah desapraja juga dianggap sejajar dengan kepala desapraja. Hal ini terlihat dari fungsi legislasi yang dimiliki, yakni dapat mengeluarkan suatu putusan yang menyangkut desapraja namun keputusan tersebut tidak dapat menjatuhkan kepala desapraja.

Perkembangan berikutnya dapat dilihat dalam pengaturan Lembaga Musyawarah Desa (LMD) menurut UU No. 5 Tahun 1979 tentang Pemerin- tahan Desa. Dalam masa ini, desa bukan daerah otonom melainkan wilayah administrastif dan terjadi penyeragaman bentuk dan susunan pemerintah desa dengan corak nasional. Hal ini dianggap menghilangkan sifat 'istimewa' desa yang bentuk dan coraknya beranekaragam. ${ }^{14}$ Pemerintahan yang sentralistik ini mempengaruhi fungsi dan kedudukan LMD. LMD merupakan unsur penyelenggara pemerintah desa, namun tidak memiliki fungsi legislasi ${ }^{15}$ karena LMD tidak dapat mengeluarkan putusan menyangkut desa. Fungsi utama LMD hanya sebagai tempat menampung aspirasi masyarakat atau semacam lembaga musyawarah rakyat desa. Kedudukan LMD berada di bawah kepala desa sehingga LMD tidak mempunyai fungsi pengawasan dan tidak dapat meminta pertanggungjawaban kepada kepala desa. Hal ini disebabkan adanya kecenderungan posisi ketua dan sekretaris LMD dijabat ex officio oleh kepala desa dan sekretaris desa itu sendiri. ${ }^{16}$

Pengaturan mengenai desa kemudian diubah kembali dengan UU No. 22 Tahun 1999 tentang Pemerintahan Daerah dimana desa kembali menjadi daerah yang istimewa dan bersifat mandiri. ${ }^{17}$ Dalam UU tersebut dikenal istilah Badan Perwakilan Desa (BPDes) yang kembali memiliki fungsi legislasi, fungsi pengawasan dan menampung/ menyalurkan aspirasi masyarakat kepada pejabat/ instansi berwenang. Namun, fungsi utama BPDes adalah menetapkan perdes bersama-sama dengan kepala desa. ${ }^{18}$

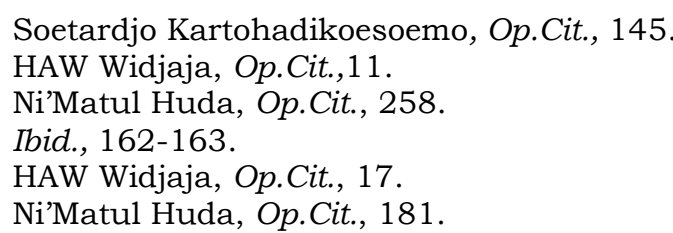


Lahirnya BPDes membawa pergeseran kekuasaan yang lebih jelas antara kepala desa sebagai pemegang kekuasaan eksekutif dan BPDes sebagai pemegang kekuasaan legislatif, 19 sehingga kepala desa dengan BPDes memiliki kedudukan yang sejajar.

Dalam UU No. 32 Tahun 2004 tentang Pemerintahan Daerah (selanjutnya disebut UU Pemerintahan Daerah), istilah BPDes diubah menjadi BPD. Istilah yang sama tetap digunakan dalam UU Desa. Hal pokok yang membedakan adalah dalam desa BPD tidak lagi menjadi unsur penyelenggara pemerintahan desa. BPD memang memiliki fungsi pemerintahan, tetapi ia berdiri sendiri di luar struktur pemerintahan desa. 20 Kepala desa tidak bertanggung jawab kepada BPD dan sebaliknya BPD tidak bertanggung jawab kepada kepala desa. Pembentukan BPD dimaksudkan untuk melibatkan masyarakat dalam pengambilan dan pembuatan keputusan di tingkat desa melalui partisipasi aktif masyarakat. ${ }^{21}$

\section{Kedudukan dan Fungsi BPD Kunjang}

BPD Kunjang memiliki jumlah anggota 10 (sepuluh) orang, dimana jumlah ini mewakili 5 (lima) dusun yang dibawahi oleh Desa Kunjang. Untuk kuota masing-masing per dusun diwakili dari 1 (satu) sampai 3 (tiga) orang dengan salah satu dasarnya pada jumlah penduduk masing-masing dusun. Penentuan anggota BPD Kunjang dilaksanakan dengan cara dipilih oleh perwakilan masyarakat desa secara musyawarah dan mufakat. Pimpinan BPD Kunjang dipilih dari dan oleh anggota BPD secara langsung. Fungsi BPD Kunjang akan dijelaskan sebagai berikut:

\section{Fungsi Pengawasan}

Dalam penyelenggaraan pemerintahan desa perlu memiliki lembaga yang memiliki hak pengawasan atas penyelanggaraan pemerintah desa oleh kepala desa. ${ }^{22}$ Sesuai dengan UU Desa, lembaga yang memiliki hak pengawasan tersebut adalah BPD. Ketika berbicara mengenai pengawasan, bidang pengawasan terhadap desa tentu tidak hanya dilakukan secara internal melalui BPD. Contohnya di Desa Kunjang sendiri selain BPD, pengawasan juga dapat dilakukan oleh Badan Pemeriksa Keuangan (BPK) terkait dengan pengawasan dana desa yang berasal dari Anggaran Pendapatan dan Belanjda Negara (APBN), kejaksaan, inspektorat, pihak kepolisian, koramil, Badan Pemberdayaan Masyarakat dan Pemerintahan Desa (BPMPD). Dalam hal pengawasan terhadap dana desa, BPD mempunyai peran yang strategis dalam ikut mengawal penggunaan dana desa. Bentuk pengawasan BPD tersebut terlihat dalam Pasal 51 ayat (2) Peraturan Pemerintah No. 43 Tahun 2014 tentang Peraturan Pelaksanaan UU Desa yang menyebut-

19 Ibid.

20 Rochmad Effendy, 'Memperkuat Fungsi dan Peran Pengawasan Badan Permusyawaratan Desa (BPD) Melalui Advokasi Hak Warga Atas Informasi Publik Untuk Membangun Tata Kelola Pemerintahan Desa' (2016) 1 Publisia Jurnal Ilmu Administrasi Publik 51, 58.

21 Panca Setyo Prihatin, 'Penguatan Fungsi Badan Permusyawaratan Desa Dalam Menampung dan Menyalurkan Aspirasi Masyarakat Desa (2016)' 2 Wedana Jurnal Pemerintahan, Politik dan Birokrasi 123, 127.

22 Siti Rodhiyah dan Muhammad Harir, 'Peranan Badan Permusyawaratan Desa (BPD) Dalam Pembentukan Peraturan Desa Di Desa Krandon Kecamatan Guntur Kabupaten Demak' (2015) 2 Jurnal Pembaharuan Hukum 291, 294. 
kan bahwa laporan keterangan penyelenggaraan pemerintahan desa paling sedikit memuat pelaksanaan perdes, dimana salah satu dan utamanya mengenai pelaksanaan perdes yang berisi tentang Anggaran Pendapatan dan Belanja Desa (APBDes). Hal ini berarti, kepala desa wajib membuat laporan keterangan tertulis tentang pelaksanaan perdes tentang pelaksanaan APBDes yang nantinya akan disampaikan kepada BPD. 23

Di Desa Kunjang sendiri, tugas utama BPD Kunjang dalam menjalankan fungsi pengawasan adalah menyeleksi rancangan program, memberikan pertimbangan/ usul /pendapat, dan memberikan persetujuan atas rancangan program. Minimal dalam satu tahun anggaran akan ada dua tugas pengawasan yang dilakukan oleh BPD Kunjang yaitu evaluasi pelaksanaan APBDesa dan pengawasan atas sewa lelang tanah kas desa.

Terkait dengan keuangan desa, tugas yang dilakukan oleh BPD Kunjang antara lain:24

a. Memberikan persetujuan atas RAPBDes. Konsep RAPBDes yang telah dibuat oleh kepala desa bersama dengan perangkat desa yang lain akan dibicarakan dalam suatu forum untuk dirundingkan, dimintakan pendapat, dan dimintakan persetujuan bersama. Dalam forum tersebut kepala desa tidak hanya mengundang BPD Kunjang, namun juga mengundang lembaga desa yang lain seperti Lembaga Pemberdayaan Masyarakat Desa (LPMD), Rukun
Tetangga (RT)/Rukun Warga (RW), tokoh masyarakat, dan tokoh agama. Dalam hal ini, apabila dalam forum tersebut RAPBDes tidak disetujui oleh BPD Kunjang, maka RAPBDes tersebut secara legalitas tidak dapat dijalankan dan ditetapkan menjadi APBDes.

b. Persetujuan BPD Kunjang tersebut menjadi acuan untuk menerima Alokasi Dana Desa (ADD) dan Dana Desa (DD). Ketika RAPBDes tidak dapat dijalankan karena tidak disetujui oleh BPD Kunjang, maka desa tidak dapat menerima plafon anggaran. Apabila hal tersebut terjadi maka akan menggunakan APBDes tahun sebelumnya.

c. Apabila terjadi perubahan proyek dalam APBDes, misalnya anggaran yang seharusnya untuk membangun tempat ibadah menjadi digunakan untuk pembangunan tanggul, maka harus dibuat Berita Acara (BA) perubahan anggaran. Apabila dalam perubahan proyek tersebut tidak terjadi penambahan atau pengurangan anggaran, maka cukup dibuat BA perubahan anggaran, namun apabila terjadi penambahan atau pengurangan anggaran, maka harus dibuat Perubahan Anggaran Keuangan (PAK). Dalam hal ini baik BA perubahan anggaran ataupun PAK akan disampaikan kembali kepada BPD Kunjang dalam suatu forum.

Secara umum pelaksanaan pengawasan oleh BPD Kunjang telah dilaksanakan secara utuh. BPD Kunjang tergolong bersifat konsultatif. Dalam

23 Darmini Roza dan Laurensius Arliman, 'Peran Badan Permusyawaratan Desa di Dalam Pembangunan Desa dan Pengawasan Keuangan Desa' (2017) 4 Padjajaran Jurnal Ilmu Hukum 606, 618.

24 Hasil wawancara dengan Ketua BPD Kunjang, Budi Santoso, tanggal 18 Agustus 2018. 
hal kemitraan, perangkat desa sering berkonsultasi kepada BPD Kunjang melalui kepala desa. BPD Kunjang dalam menjalankan fungsi pengawasan kinerja kepala desa tidak dapat memberikan sanksi secara langsung kepada kepala desa maupun perangkat desa lainnya. Namun, BPD Kunjang berhak untuk menegur kepala desa atau perangkat desa, tidak menyetujui rancangan program yang diajukan oleh kepala desa atau perangkat desa, melaporkan kepada pihak yang berwenang apabila terjadi pelanggaran hukum ataupun maladministrasi, hingga memberikan peringatan (somasi) kepada perangkat desa dan menyatakan mosi tidak percaya terhadap kepala desa sehingga menuntut adanya pertanggungjawaban dari kepala desa.

Sebagai perbandingan dengan desa lain, Kepala BPD Kunjang menceritakan satu kasus di desa lain, yaitu di Desa Ngadi Luwih, dimana Kepala Desa Ngadi Luwih menggunakan dana desa untuk membangun tanggul, dimana pembangunan tanggul tersebut seharusnya menjadi kewenangan kabupaten/kota dan kewenangan provinsi. Saat itu Kepala Desa Ngadi Luwih tidak mengajak BPD Ngadi Luwih untuk berdiskusi bersama, bahkan BPD Ngadi Luwih sudah memberikan peringatan bahwa penggunaan dana desa untuk pembangunan tanggul yang sebenarnya bukan kewenangan desa tersebut sudah termasuk maladministrasi. Namun Kepala Desa Ngadi Luwih tetap menjalankan proyek pembangunan tanggul tersebut, sehingga BPD Ngadi Luwih akhirnya melaporkan kepala desa tersebut dan sekarang Kepala Desa Ngudi Luwih tersebut sudah ditahan dengan dasar laporan dari BPD Ngadi Luwih. ${ }^{25}$

Pengawasan yang dilakukan oleh BPD Kunjang diakui cenderung efektif. Namun terkadang peran BPD Kunjang dalam menjalankan fungsi pengawasan dikalahkan oleh faktor budaya dan adat istiadat yang ada. Dimana dalam budaya Jawa, terutama di Desa Kunjang, apabila terlalu kritis akan dirasa kurang santun/ kurang sopan, atau adanya rasa sungkan untuk mengkritik kesalahan orang lain. Selain itu, misalnya adanya "lingkaran keluarga" dalam ruang lingkup antara perangkat desa dengan BPD Kunjang yang membuat pengawasan BPD Kunjang terkadang tidak efektif. ${ }^{26}$

\section{Fungsi Legislasi}

Apabila melihat perspektif Permendagri No. 111 Tahun 2014 tentang Pedoman Teknis Peraturan di Desa, dinyatakan bahwa penyusunan raperdes diprakarsai oleh pemerintah desa (kepala desa dan perangkat desa), sedangkan BPD memiliki fungsi legislasi pada tahap penyusunan raperdes (kecuali raperdes tentang pembangunan jangka menengah desa, rencana kerja pemerintah desa dan APBDes), tahap pembahasan perdes dan menyepakati perdes bersama kepala desa. Dalam praktik di Desa Kunjang hampir seluruh konsep raperdes berasal dari inisiatif kepala desa dan perangkat desa. Penulis berpendapat bahwa hal ini menunjukkan fungsi legislasi di Desa Kunjang menjadi tugas dan tanggung jawab utama dari pemerintah desa (kepala

\footnotetext{
25 Hasil wawancara dengan Kepala Desa Kunjang, Yudiono, tanggal 18 Agustus 2018.

26 Hasil wawancara dengan Kepala Urusan Pemerintahan Desa Kunjang, Adi Santoso, tanggal 19 Agustus 2018.
} 
desa dan perangkat desa) dan bukan menjadi tugas dan tanggung jawab utama dari BPD Kunjang. Hal ini tentu menjadi perbedaan utama jika membandingkan fungsi legislasi yang dimiliki oleh DPRD ataupun DPR dengan fungsi legislasi yang dimiliki oleh BPD khususnya di Desa Kunjang. Dimana di tingkat pusat atau daerah, fungsi legislasi (pembuatan UU/ peraturan daerah) menjadi tanggung jawab utama dari DPR/DPRD dan bukan presiden/ kepala daerah, sedangkan di tingkat desa khususnya di Desa Kunjang, fungsi legislasi menjadi tugas dan tanggung jawab utama dari Kepala Desa Kunjang bersama dengan Perangkat Desa Kunjang dan bukan berada pada BPD Kunjang.

Raperdes di Desa Kunjang dimulai dengan pembuatan konsep raperdes yang dibuat oleh kepala desa bersama dengan perangkat desa lainnya. Setelah konsep raperdes selesai dibuat, maka konsep raperdes tersebut akan dibicarakan dalam sebuah forum, sehingga dalam forum tersebut sudah ada konsep raperdes terlebih dahulu. Dalam forum tersebut raperdes akan dikonsultasikan kepada BPD Kunjang. Dalam hal ini BPD Kunjang berperan dalam memberikan kontribusi, apabila ada bagian-bagian dalam konsep tersebut yang dirasa tidak relevan maka BPD akan dimintakan saran bagian mana yang harus diubah. Apabila ada bagianbagian yang dianggap tidak masuk akal BPD juga dapat mempertanyakan hal-hal tersebut. Contoh Perdes Kunjang yang berhasil dibuat bersama dengan BPD Kunjang dan dirasakan sangat memberikan manfaat adalah Peraturan Desa Kunjang tentang Pengelolaan Aset Desa. ${ }^{27}$

Di Desa Kunjang, karena konsep raperdes itu dibuat oleh kepala desa, maka dapat dipahami jika kepala desa selalu menandatangani perdes yang telah disepakati bersama. Sebaliknya, apabila BPD yang tidak menyetujui konsep raperdes tersebut, maka langkah yang dilakukan adalah BPD akan dimintakan usulan perubahan seperti yang telah dijelaskan sebelumnya. Di Desa Kunjang pernah terjadi hal seperti itu pada tahun 2015, dimana saat itu terkait pembuatan peraturan tentang anggaran untuk pemilihan kepala desa. Saat itu terjadi ketidaksepahaman dan ketidaksepakatan antara BPD dengan kepala desa dan perangkat desa lainnya bahkan berujung pada dead lock. Saat terjadi dead lock seperti itu, pada akhirnya rancangan peraturan anggaran pemilihan kepala desa tadi tidak dapat ditetapkan menjadi peraturan desa dan dibiarkan "menggantung" begitu saja. Hal yang dilakukan kemudian adalah membuat berita acara yang intinya berisikan mengenai terjadinya dead lock, dan disampaikan kepada bupati melalui camat. Daerah kabupaten yang seharusnya memfasilitasi, namun apabila kabupaten mengabaikan maka akan tetap dibiarkan "menggantung" tanpa putusan apapun. ${ }^{28}$

3. Menampung dan Menyalurkan Aspirasi Masyarakat Desa

BPD seyogyanya merupakan wadah demokrasi untuk menampung aspirasi masyarakat desa. Untuk

\footnotetext{
27 Hasil wawancara dengan Kepala BPD Kunjang, Budi Santoso dan Kepala Dusun Pulung Suwantoro, tanggal 18 Agustus 2018.

28 Hasil wawancara dengan Kepala Urusan Pemerintahan Desa Kunjang, Adi Santoso, tanggal 19 Agustus 2018.
} 
mewujudkan fungsi tersebut, BPD harus terpisah dan bebas dari kepentingan partai politik. Sesuai dengan Pasal 26 Pemendagri No. 110 Tahun 2016 tentang Badan Permusyawaratan Desa, anggota BPD di Desa Kunjang dimungkinkan berasal dari anggota partai politik, namun tidak diperbolehkan berasal dari pengurus partai politik, bahkan hingga pengurus anak ranting di tingkat dusun. Dalam hal ini penulis berpendapat kebijakan anggota BPD yang tidak boleh berasal dari pengurus partai politik sudah sangat baik. Penulis menyetujui bahwa sudah seharusnya BPD dipisahkan dengan partai politik, untuk memberikan "warna yang berbeda" dengan DPRD di tingkat kabupaten/kota. Dengan kebijakan tersebut diharapkan BPD Kunjang dapat seutuhnya menjadi wadah untuk menyuarakan kepentingan masyarakat desa tanpa membawa kepentingan partai politik manapun.

Salah satu forum yang paling sering digunakan BPD Kunjang untuk menampung dan menyalurkan aspirasi masyarakat adalah musyawarah desa, dimana di dalam musyawarah desa tersebut BPD Kunjang akan mengundang perwakilan masyarakat yang berasal dari lembaga desa, RT/RW, LPMD, Pemberdayaan Kesejahteraan Keluarga (PKK), karang taruna, tokoh agama dan tokoh masyarakat untuk membicarakan halhal yang menyangkut desa. Jumlah perwakilan dari setiap unsur tersebut memiliki batasan, sebagai contoh untuk tokoh agama dan tokoh masyarakat yang diundang dalam musyawarah desa dibatasi rata-rata 7 (tujuh) orang untuk setiap dusun. Di
Desa Kunjang, pertemuan yang boleh dihadiri oleh seluruh masyarakat desa adalah pembentukan panitia pemilihan kepala desa setiap 6 (enam) tahun sekali. Dalam hal ini menunjukkan bahwa demokrasi yang terjadi adalah demokrasi tidak langsung atau melalui perwakilan. Hal ini berbeda dengan konsep demokrasi langsung yang terjadi pada masa dulu, dimana setiap warga desa berhak untuk ikut dalam suatu rapat desa.

Selain musyawarah desa masih banyak forum yang digunakan oleh BPD Kunjang untuk menampung aspirasi masyarakat. Secara teknis, pengambilan keputusan di BPD Desa Kunjang dilakukan secara musyawarah, terkadang dilakukan dengan voting terbuka. ${ }^{29}$

\section{Pengaruh Pergeseran Kedudukan BPD Dalam UU Desa Terhadap Kedudukan dan Fungsi BPD Kunjang}

Pada tahun 1999 ketika masih bernama BPDes, fungsi pengawasan BPDes Kunjang tidak begitu dirasakan oleh masyarakat Desa Kunjang. BPDes Kunjang saat itu ibarat "penumpang" dalam pemerintah desa yang cukup mengikuti kemana arah arus pemerintah desa. Keadaan politik saat itu mempengaruhi pengaturan mengenai fungsi BPD, dimana menurut UU Pemerintahan Daerah, BPD tidak memiliki fungsi pengawasan. Akibatnya, fungsi BPD Kunjang lebih diarahkan sebagai fungsi perwakilan yang mewakili kepentingan masyarakat desa. Sebagai akibatnya, suara BPD Kunjang dianggap sama dengan suara masyarakat desa, sehingga suara yang diberikan oleh BPD Kunjang tersebut memberikan kesan

29 Hasil wawancara dengan Ketua BPD Kunjang, Budi Santoso, tanggal 18 Agustus 2018. 
cenderung "harus dilaksanakan" oleh pemerintah desa. Di satu sisi hal tersebut tidak dapat sepenuhnya dilaksanakan, karena tidak mungkin jika pemerintah desa "harus selalu" melaksanakan suara BPD. Pemerintah desa harus mempertimbangkan halhal lain seperti tata cara, aturan dan rasionalitas sebelum melaksanakan apa yang diminta oleh BPD. ${ }^{30}$

Selain itu, dalam praktiknya karena BPD dan kepala desa samasama sebagai unsur pemerintahan desa dan bersama-sama menyelenggarakan pemerintahan desa, hal tersebut mengakibatkan BPD Kunjang saat itu memiliki fungsi dan kewenangan yang hampir sama dengan kepala desa. Oleh sebab itu, intervensi BPD Kunjang justru dianggap terlalu besar kepada kepala desa ataupun perangkat desa lain. Sebagai contoh, ketika kepala desa ingin memilih personilnya sendiri untuk membantu tugas-tugasnya, yang sesungguhnya hal tersebut merupakan hak mutlak yang dimiliki oleh kepala desa, namun intervensi BPD justru sangat besar. Kewenangan Kepala Desa dan BPD Kunjang yang hampir sama tersebut terkadang menimbulkan adanya tumpang tindih kewenangan antara Kepala Desa dengan BPD Kunjang dan menimbulkan dua kekuasaan dalam pemerintahan Desa Kunjang. Jika diumpamakan, Desa Kunjang saat itu seakan mempunyai "dua matahari" atau "dua komando" dalam pemerintahan desa, yaitu kepala desa dan BPD. 31

Pada masa sekarang setelah dikeluarkannya UU Desa, BPD Kunjang "dikembalikan" kedudukan- nya menjadi mitra bagi pemerintah desa. Fungsi utama BPD Kunjang kembali difokuskan pada fungsi kontrol dan pengawasan yang ditunjang dengan hak insentif bagi BPD. BPD Kunjang tidak lagi menjadi unsur penyelenggara pemerintahan desa, namun bukan berarti BPD Kunjang berada di bawah komando kepala desa dan bertanggung jawab kepada kepala desa. BPD Kunjang bekerja dan menjalankan fungsi pemerintahan sebagai "mitra" bagi pemerintahan desa. Sebagai "mitra" bagi kepala desa dan perangkat desa lain yang berada di luar penyelenggara pemerintahan, BPD Kunjang tidak dapat lagi melakukan intervensi terhadap kewenangan kepala desa sehingga tidak lagi terjadi tumpang tindih kewenangan dan tidak menimbulkan dua kekuasaan dalam pemerintahan. Namun bukan berarti pengawasan yang dilakukan BPD benar-benar sama dengan yang dulu, dimana suara BPD sebagai unsur pemerintahan desa "harus" dilaksanakan oleh kepala desa atau perangkat desa lainnya. Pengawasan yang dilakukan BPD sebagai "mitra" kepala desa dan perangkat desa dilakukan sesuai dengan pedoman yang berlaku yang tetap berdasarkan aturan, tata cara, dan rasionalitas dengan melihat faktor sosial, adat, dan budaya yang ada di Desa Kunjang.

Pengaruh pergeseran kedudukan dan fungsi BPD Kunjang dapat disimpulkan dalam perbandingan dari aspek kedudukan, fungsi pengawasan, fungsi legislasi dan fungsi perwakilan sebelum dan sesudah adanya UU Desa beserta pengaruhnya

30 Hasil wawancara dengan Kepala Urusan Pemerintahan Desa Kunjang, Adi Santoso dan Kepala Dusun Pulung Suwantoro, tanggal 19 Agustus 2018.

31 Hasil wawancara dengan Kepala Urusan Pemerintahan Desa Kunjang, Adi Santoso dan Kepala Dusun Pulung Suwantoro, tanggal 19 Agustus 2018. 
seperti dijelaskan sebagai berikut:

\section{a. Kedudukan}

Sebelum adanya UU Desa, kedudukan BPD sejajar dengan kepala desa dan bertindak sebagai penyelenggara pemerintahan desa. Kedudukan BPD tersebut memberikan pengaruh terhadap beberapa hal, yaitu: pertama, fungsi dan kewenangan yang dimiliki BPD Kunjang hampir sama dengan kepala desa. Kedua, intervensi BPD Kunjang terhadap kewenangan kepala desa ataupun perangkat desa lain dianggap terlalu besar. Ketiga, menimbulkan adanya tumpang tindih kewenangan dan dua kekuasaan/dua komando (Kepala Desa dan BPD Kunjang) dalam Pemerintahan Desa Kunjang.

Setelah adanya UU Desa kedudukan BPD dengan kepala desa tetap sama akan tetapi BPD berada di luar penyelenggara pemerintahan desa. Perubahan aturan tersebut juga merubah pengaruh BPD. Pertama, BPD Kunjang berkedudukan sebagai mitra bagi pemerintah desa (kepala desa dan perangkat desa). Kedua, tidak ada lagi intervensi BPD Kunjang terhadap kewenangan kepala desa sehingga tidak lagi terjadi tumpang tindih kewenangan dan tidak menimbulkan 2 (dua) kekuasaan/ 2 (dua) komando dalam Pemerintahan Desa Kunjang.

\section{b. Fungsi Pengawasan}

Sebelum UU Desa berlaku, tidak ada kaidah yang mengatur mengenai fungsi pengawasan BPD. Dalam UU No. 22 Tahun 1999, BPD memiliki fungsi pengawasan, namun fungsi pengawasan BPD Kunjang tidak efektif. Sedangkan dalam UU Pemerintahan Daerah, BPD tidak memiliki fungsi pengawasan. Akibatnya, BPD Kunjang tidak memiliki fungsi pengawasan dan fungsi perwakilan BPD Kunjang terlalu besar, sehingga muncul anggapan semua suara BPD Kunjang harus selalu dilaksanakan.

Setelah berlakunya UU Desa, BPD memiliki fungsi pengawasan. Fungsi pengawasan ini menjadi fungsi utama dari BPD Kunjang. Akan tetapi, tidak sama seperti sebelumnya dimana setiap suara BPD Kunjang harus selalu dilaksanakan oleh kepala desa dan perangkat desa.

\section{c. Fungsi Legislasi}

Sebelum UU Desa berlaku, BPD memiliki fungsi legislasi pada tahap inisiasi raperdes, tahap pembahasan raperdes dan menetapkan perdes bersama kepala desa. Hal ini memiliki pengaruh terkait inisiatif dalam membuat konsep raperdes berasal dari Kepala Desa dan BPD Kunjang. Setelah berlakunya UU Desa, BPD tetap memiliki fungsi legislasi pada tahap inisiasi, tahap pembahasan dan menyepakati perdes bersama kepala desa. Akan tetapi terdapat pengeculian fungsi legislasi BPD pada tahap inisiasi, yakni BPD tidak ikut terlibat dalam raperdes tentang pembangunan jangka menengah desa, rencana kerja pemerintah desa dan APBD. Akibat dari pengecualian tersebut, hampir seluruh konsep raperdes hanya berasal dari inisiatif kepala desa dan perangkat desa. Selain itu, fungsi legislasi menjadi tugas dan tanggung jawab utama dari pemerintah desa (kepala desa dan perangkat desa) dan bukan menjadi tugas dan tanggung jawab utama dari BPD Kunjang. Diketahui pula dalam praktik, fungsi legislasi BPD Kunjang sebatas memberikan kontribusi berupa saran 
atau pertanyaan terhadap konsep raperdes.

\section{d. Fungsi Perwakilan}

Sebelum masa kemerdekaan, rapat desa tidak memiliki fungsi perwakilan. Fungsi perwakilan mulai terlihat sejak masa reformasi. Pengaruh fungsi perwakilan tersebut, rapat desa sebagai embrio dari BPD menganut konsep demokrasi langsung, dimana setiap warga desa berhak untuk ikut dalam rapat desa. Sejak masa reformasi BPD menggunakan konsep demokrasi melalui perwakilan.

Setelah berlakunya UU Desa, BPD memiliki fungsi perwakilan dengan konsep demokrasi melalui perwakilan. Hal ini mempengaruhi dua hal yaitu: pertama, BPD Kunjang masih dapat dikatakan sebagai lembaga yang mewakili masyarakat desa; dan kedua, demokrasi yang dianut oleh BPD Kunjang tidak lagi demokrasi langsung, melainkan demokrasi melalui perwakilan masyarakat desa.

\section{PENUTUP}

Pengaruh pergeseran kedudukan dan fungsi BPD berbeda di masingmasing desa. Pengaturan mengenai BPD di dalam peraturan perundangundangan untuk ke depannya perlu memperhatikan faktor sosial, budaya dan adat yang berlaku di masingmasing desa. Setiap desa mempunyai ciri khas masing-masing yang harus tetap dipertahankan, karena hal tersebut yang membuat sifat "istimewa" dari desa. Selain itu, keaslian desa seperti demokrasi langsung yang diterapkan oleh rapat desa pada masa sebelum kemerdekaan, penegasan kewenangan BPD dalam pembentukan perdes dan penegasan kewenangan BPD sebagai penasehat bagi penyelenggara pemerintahan desa (kepala desa dan perangkat desa) harus diperhatikan apabila ke depannya akan dilakukan perubahan atas aturan BPD dalam UU Desa.

\section{DAFTAR BACAAN}

\section{Buku}

Fadli, Moh., dkk, Pembentukan Peraturan Desa Partisipatif (UB Press 2011).

Huda, N., Hukum Pemerintahan Desa Dalam Konstitusi Indonesia Sejak Kemerdekaan Hingga Era Reformasi (Setara Press 2015).

Kartohadikoesoemo, S., Desa (Yogyakarta 1953).

Ndaraha, T., Dimensi-Dimensi Pemerintahan Desa (PT Bina Karya 1991).

Saparin, Tata Pemerintahan dan Administrasi Pemerintahan Desa (Ghalia Indonesia 1977).

Sunardjo, U., Tinjauan Singkat Tentang Pemerintahan Desa dan Kelurahan (Tarsito 1984).

Widjaja, HAW., Otonomi Desa Merupakan Otonomi Yang Asli, Bulat, dan Utuh (Rajawali Press 2014).

\section{Artikel Jurnal}

Effendy, R., 'Memperkuat Fungsi dan Peran Pengawasan Badan Permusyawaratan Desa (BPD) Melalui Advokasi Hak Warga Atas Informasi Publik Untuk Membangun Tata Kelola Pemerintahan Desa' (2016) 1 Publisia Jurnal Ilmu Administrasi Publik. 
Prihatin, Panca S., 'Penguatan Fungsi Badan Permusyawaratan Desa Dalam Menampung dan Menyalurkan Aspirasi Masyarakat Desa (2016)' 2 Wedana Jurnal Pemerintahan, Politik dan Birokrasi.

Rodhiyah, S., dan Harir, M., 'Peranan Badan Permusyawaratan Desa (BPD) Dalam Pembentukan Peraturan Desa di Desa Krandon Kecamatan Guntur Kabupaten Demak' (2015) 2 Jurnal Pembaharuan Hukum.

Roza, D., dan Arliman, L., 'Peran Badan Permusyawaratan Desa di Dalam Pembangunan Desa dan Pengawasan Keuangan Desa' (2017) 4 Padjajaran Jurnal Ilmu Hukum.

Setiawati, 'Peran Badan Permusyawaratan Desa Dalam Penyusunan Dan Penetapan Peraturan Desa' (2018) 5 Jurnal Pendidikan dan Kewarganegaraan Unpam.

\section{Peraturan Perundang-Undangan}

Undang-Undang Dasar Negara Republik Indonesia Tahun 1945.

Undang-Undang Nomor 19 Tahun 1965 tentang Desapraja Sebagai Bentuk Peralihan Untuk Mempercepat Terwujudnya Daerah Tingkat III Di Seluruh Wilayah Republik Indonesia.

Undang-Undang Nomor 5 Tahun 1979 tentang Pemerintahan Desa.

Undang-Undang Nomor 22 Tahun 1999 tentang Pemerintahan Daerah.

Undang-Undang Nomor 32 Tahun 2004 tentang Pemerintahan Daerah.
Undang-Undang Nomor 6 Tahun 2014 tentang Desa.

Peraturan Pemerintah Nomor 43 Tahun 2014 tentang Peraturan Pelaksanaan Undang-Undang Nomor 6 Tahun 2014 tentang Desa.

Peraturan Menteri Dalam Negeri Nomor 111 Tahun 2014 tentang Pedoman Teknis Peraturan Di Desa.

Peraturan Menteri Dalam Negeri Nomor 110 Tahun 2016 tentang Badan Permusyawaratan Desa. 